Farm animal welfare - who writes the rules?

Occasional Publication No. 23 - British Society of Animal Science 1999

edited by A. J. F. Russel, C. A. Morgan, C. J. Savory, M. C. Appleby and T. L. J. Lawrence

\title{
Perception of farm treatment of various livestock in Zaragoza (Spain)
}

\author{
G. A. María, J. L. Olleta and M. L. Mocé \\ Animal Production Department, University of Zaragoza, Miguel Servet 177, 50013 Zaragoza, Spain
}

\section{Introduction}

Livestock production in intensive conditions has resulted in considerable criticism by various segments of society. The animal rights movement has developed rapidly in northern Europe and North America. The strong social claim in favour of animal welfare has produced important changes in the European legislation controlling livestock industries in the EU. As a consequence of these changes it will be necessary to introduce important modifications in the production systems which could affect production costs. The question is to determine whether people in southern European countries such as Spain will accept the increment in the price of the products in order to improve farm animal welfare. The objective of this study was to assess the perception of farm animal treatment of various livestock of people with urban backgrounds.

\section{Material and methods}

The human attitude and perception of farm animal treatment of various livestock were examined in a selected sample of 956 people living in Zaragoza
(700 000 inhabitants city in NE Spain) during the years 1995, 1996 and 1997. The study used the 'feeling thermometer' with a scale ranging from 0 to 100 , with 0 being a very cool or negative response and 100 being a very warm or positive response (Jamison, 1992). The survey included the following questions. (1) Do you eat animal products? (yes, no). (2) What is your 'feeling' about animal treatment or animal welfare in the farms? (very good, good, fair, bad, very bad). (3) Using a scale from 0 (very bad treatment) to 100 (very good treatment), give a score to the following livestock: horses, sheep, beef cows, dairy cows, goats, veal calves, swine, rabbits, turkeys, broilers and layers. People were also asked about their willingness to pay more for an animal product in order to improve farm animal welfare.

For the analysis, animals were assembled in two groups: group 1 (ruminants and horses) and group 2 (swine, rabbits, and poultry). Descriptive statistics were calculated and the fixed effects of sex ( 2 levels: male and female), age ( 3 levels: $<30 ; 30-45$ and $>45$ years old), occupation (4 levels: student, worker, professional and housewife), and animal group (2

Table 1 Two-way frequency table by sex, age and occupation of people perception on farm animal treatment and the willingness to pay more for an animal product to improve the welfare of the animals

\begin{tabular}{|c|c|c|c|c|c|c|c|}
\hline \multirow[b]{2}{*}{ Variables } & \multicolumn{5}{|c|}{ View on the farm animal treatment } & \multicolumn{2}{|c|}{$\begin{array}{l}\text { Pay more for a product to } \\
\text { improve animal welfare }\end{array}$} \\
\hline & Very good & Good & Fair & Bad & Very bad & Yes & No \\
\hline $\begin{array}{l}\text { Overall frequency \% } \\
\text { Gender }\end{array}$ & $2 \cdot 90$ & $25 \cdot 20$ & $45 \cdot 10$ & $17 \cdot 20$ & $9 \cdot 00$ & $72 \cdot 80$ & $26 \cdot 50$ \\
\hline $\begin{array}{l}\text { male } \% \\
\text { female } \%\end{array}$ & $\begin{array}{l}3 \cdot 42 \\
2 \cdot 47\end{array}$ & $\begin{array}{l}27 \cdot 78 \\
22 \cdot 63\end{array}$ & $\begin{array}{l}43 \cdot 16 \\
46 \cdot 91\end{array}$ & $\begin{array}{l}17 \cdot 52 \\
16 \cdot 87\end{array}$ & $\begin{array}{r}7.69 \\
10 \cdot 29\end{array}$ & $\begin{array}{l}62.39 \\
82.99\end{array}$ & $\begin{array}{l}37 \cdot 18 \\
16 \cdot 18\end{array}$ \\
\hline Age & & & & & & & \\
\hline $\begin{array}{l}<35 \% \\
35-45 \% \\
>45 \%\end{array}$ & $\begin{array}{l}1 \cdot 11 \\
8 \cdot 33 \\
8 \cdot 82\end{array}$ & $\begin{array}{l}21 \cdot 08 \\
37 \cdot 50 \\
33 \cdot 82\end{array}$ & $\begin{array}{l}48 \cdot 20 \\
29 \cdot 17 \\
39 \cdot 71\end{array}$ & $\begin{array}{l}18 \cdot 28 \\
14 \cdot 58 \\
13 \cdot 24\end{array}$ & $\begin{array}{r}10 \cdot 53 \\
8 \cdot 33 \\
1 \cdot 47\end{array}$ & $\begin{array}{l}74 \cdot 65 \\
60 \cdot 42 \\
72 \cdot 06\end{array}$ & $\begin{array}{l}25 \cdot 07 \\
39 \cdot 58 \\
25 \cdot 00\end{array}$ \\
\hline Occupation & & & & & & & \\
\hline $\begin{array}{l}\text { Student \% } \\
\text { Worker \% } \\
\text { Professional \% } \\
\text { Housewife \% }\end{array}$ & $\begin{array}{l}0.00 \\
4 \cdot 81 \\
6 \cdot 10 \\
9 \cdot 68\end{array}$ & $\begin{array}{l}14 \cdot 29 \\
28 \cdot 85 \\
24 \cdot 39 \\
32 \cdot 26\end{array}$ & $\begin{array}{l}42 \cdot 86 \\
35 \cdot 58 \\
34 \cdot 15 \\
54 \cdot 84\end{array}$ & $\begin{array}{r}21 \cdot 43 \\
10 \cdot 58 \\
30 \cdot 49 \\
3 \cdot 23\end{array}$ & $\begin{array}{r}21 \cdot 43 \\
19 \cdot 23 \\
3.66 \\
0.00\end{array}$ & $\begin{array}{l}85 \cdot 71 \\
67 \cdot 31 \\
67 \cdot 07 \\
80 \cdot 65\end{array}$ & $\begin{array}{l}14 \cdot 29 \\
32 \cdot 69 \\
30 \cdot 49 \\
19 \cdot 35\end{array}$ \\
\hline
\end{tabular}


Table 2 Mean scores on farm animal treatment of various livestock by sex, age and occupation and the overall mean score ( \pm s.d.)

\begin{tabular}{|c|c|c|c|c|c|c|c|c|c|c|}
\hline \multirow[b]{2}{*}{ Livestock } & \multirow{2}{*}{$\begin{array}{l}\text { Overall } \\
\text { mean }\end{array}$} & \multicolumn{2}{|c|}{ Gender } & \multicolumn{3}{|c|}{ Age } & \multicolumn{4}{|c|}{ Occupation } \\
\hline & & Males & Female & $<35$ & $35-45$ & $>45$ & Student & Worker & Professional & House-wife \\
\hline \multicolumn{11}{|l|}{ Group 1} \\
\hline Horses & $76 \pm 20$ & 77 & 75 & 75 & 77 & 81 & 76 & 73 & 78 & 79 \\
\hline Sheep & $56 \pm 22$ & 50 & 56 & 54 & 57 & 66 & 39 & 54 & 55 & 69 \\
\hline Beef & $52 \pm 23$ & 54 & 51 & 49 & 58 & 68 & 44 & 50 & 53 & 72 \\
\hline Dairy & $59 \pm 24$ & 60 & 58 & 56 & 62 & 72 & 39 & 57 & 58 & 75 \\
\hline Goat & $53 \pm 22$ & 56 & 51 & 51 & 57 & 64 & 46 & 52 & 54 & 65 \\
\hline Veal & $55 \pm 22$ & 55 & 54 & 51 & 58 & 71 & 43 & 52 & 53 & 74 \\
\hline Average & $58 \pm 18$ & 59 & 58 & 56 & 62 & 70 & 48 & 57 & 59 & 72 \\
\hline \multicolumn{11}{|l|}{ Group 2} \\
\hline Swine & $42 \pm 24$ & 42 & 40 & 38 & 44 & 53 & 31 & 42 & 39 & 50 \\
\hline Rabbit & $41 \pm 24$ & 42 & 40 & 38 & 43 & 57 & 25 & 41 & 40 & 59 \\
\hline Turkey & $45 \pm 25$ & 46 & 43 & 42 & 50 & 55 & 28 & 43 & 46 & 52 \\
\hline Broiler & $36 \pm 25$ & 37 & 35 & 33 & 42 & 50 & 24 & 35 & 35 & 54 \\
\hline Layer & $42 \pm 27$ & 43 & 41 & 39 & 44 & 58 & 25 & 43 & 39 & 52 \\
\hline Average & $40 \pm 22$ & 42 & 38 & 37 & 44 & 53 & 29 & 39 & 39 & 52 \\
\hline
\end{tabular}

levels) were analysed using a factorial model (Statistical Analysis Systems Institute, 1988).

\section{Results}

Frequencies showing the distribution by sex, age and occupation of the answers about farm animal treatment and the willingness to pay more for an

Table 3 Significance probabilities for fixed effects from the analysis of variance of the scores

\begin{tabular}{|c|c|c|c|c|}
\hline \multirow{2}{*}{$\begin{array}{l}\text { Livestock } \\
\text { group }\end{array}$} & \multicolumn{4}{|c|}{ Source of variation } \\
\hline & Gender & Age & Occupation & Animal \\
\hline \multicolumn{5}{|l|}{ Group 1} \\
\hline Horse & & $* * *$ & $*$ & NM \\
\hline Sheep & & $* * *$ & $* * *$ & NM \\
\hline Beef cow & $*$ & $* * *$ & $* * *$ & NM \\
\hline Dairy cow & & $* * *$ & $* * *$ & NM \\
\hline Veal calf & & $* * *$ & $* * *$ & NM \\
\hline Goat & $* * *$ & $* * *$ & $* * *$ & NM \\
\hline Average & & & & \\
\hline group 1 & & $* * *$ & $* * *$ & NM \\
\hline \multicolumn{5}{|l|}{ Group 2} \\
\hline Swine & & $* * *$ & ** & NM \\
\hline Rabbit & & $* * *$ & $* * *$ & NM \\
\hline Turkey & * & $* * *$ & $* *$ & NM \\
\hline Broiler & & $* * *$ & $* * *$ & NM \\
\hline Layer & & $* * *$ & $* * *$ & NM \\
\hline Average & & & & \\
\hline group 2 & * & $* * *$ & $* * *$ & NM \\
\hline Average & & & & \\
\hline $1+2$ & * & $* * *$ & $* * *$ & $* * *$ \\
\hline
\end{tabular}

NM: not in the model. animal product to improve animal welfare are presented in Table 1. The distribution of the answers along the treatment classes (very good, good, fair, bad and very bad) were similar in males and females. Nevertheless, women seem to be more predisposed to pay more for the product in order to improve animal welfare. Differences between age classes were more evident. The answers of young people seem to be more biased to the negative extreme (bad treatment) than those observed for middle age people, which were less willing to pay an extra charge for the animal products. Between the occupation classes the answers of the students and professionals (qualified workers) were more biased to the negative (more critical) than those observed for non-qualified workers.

Overall mean score and the mean score assigned to each livestock by sex, age and occupation are presented in Table 2. In general, livestock of the first group (ruminants and horses) are scored higher than those included in the second group. It is evident that the greater the perception of intensity and industrialization of the production (group 2), the more negative the perception.

Significance probabilities for fixed effects from the analysis of variance of the scores are presented in Table 3. The effects of age and occupation were highly significant for the scores assigned to the livestock and the livestock group. No significant effect of sex was observed. The first group (ruminants and horses) received a significantly higher score than the second group (swine, poultry and rabbits), in agreement with the observation described in Table 1. Similar results were observed 
by Jamison (1992). The comparison of the results obtained by this author with our results, indicate that people in Spain are less sensitive to farm animal welfare concerns than in USA.

Conclusions

A high proportion of the people in Spain seemed to be ready to pay more for the product, if this greater price would guarantee better welfare for the animals (all of them depending in their economic capacity). The higher the perception of industrialization of the production, the more negative was the perception. Furthermore, the belief that the animals have the same feeling and emotions as humans (anthropomorphism) was perceived in the answers. Young and old people, students and professionals were more in favour of animal welfare than middle age people and non-qualified workers. There was a trend indicating a warm or positive response in women. In general, people did not understand the animal production systems because of their urban background and they need to be informed and educated.

\section{Acknowledgements}

This study was supported by the Comision Interministerial de Ciencia y Tecnologia (CICYT) of Spain.

\section{References}

Jamison, W. 1992. The rights of animals, political activism, and the feed industry. In Biotechnology in the feed industry, (ed. T. P. Lyons), pp. 121-138. Proceedings of the Alltech eighth annual symposium, Alltech Technical Publications, Nicholasville, KY.

Statistical Analysis Systems Institute. 1988. SAS/STATS user's guide (release 6.03). SAS Institute, Inc., Cary, NC. 